\title{
Pengaruh"VISIP - HB" Terhadap Perubahan Pengetahuan dan Sikap Pencegahan Hepatitis B Wanita Pra Konsepsi
}

\author{
Anjar Astuti, Dina Dewi Anggraini \\ Jurusan Kebidanan; Poltekkes Kemenkes Semarang \\ Jl. Tirto Agung; Pedalangan; Banyumanik; Semarang, (082243646986) \\ Anjarastuti99@gmail.com, dewidina90@gmail.com
}

\begin{abstract}
ABSTRAK
Indonesia menjadi negara dengan penderita Hepatitis B ketiga terbanyak di dunia, sebanyak 28 juta penderita. Penyakit Hepatitis B dapat menyerang semua umur, tidak terkecuali ibu hamil. Jika janin terinfeksi virus hepatitis B dapat mengakibatkan bayi prematur, BBLR, kelainan anatomi dan fungsi tubuh bayi. Salah satu faktor penyebab tingginya kejadian hepatitis $B$ adalah rendahnya pengetahuan dan kesadaran masyarakat terhadap penyakit tersebut. video animasi merupakan salah satu media yang dapat digunakan untuk meningkatkan pengetahuan kepada masyarakat tentang hepatitis $B$ dan mempunyai banyak kelebihan dibandingkan dengan media lain. Tujuan penelitian ini untuk menganalisis pengaruh "VISIP - HB" terhadap perubahan pengetahuan dan sikap pencegahan Hepatitis B wanita pra konsepsi. Penelitian ini menggunakan desain quasi experimental research dengan sampel 50 wanita pra konsepsi. Analisis bivariate dengan independent $t$-test. Hasil menunjukkan ada perbedaan pengetahuan wanita pra konsepsi tentang pencegahan hepatitis $\mathrm{B}$ pada kehamilan pada kelompok kontrol dan kelompok perlakuan dengan nilai p 0,000. Ada perbedaan sikap wanita pra konsepsi tentang pencegahan hepatitis $B$ saat hamil pada kelompok kontrol dan kelompok perlakuan dengan nilai $p 0,000$. Ada pengaruh "VISIP - HB" terhadap perubahan pengetahuan dan sikap wanita pra konsepsi dalam mencegah hepatitis B saat hamil.
\end{abstract}

Kata kunci: pengetahuan; sikap; video; wanita pra konsepsi

\section{The Effect of "VISIP - HB" on Knowledge and Attitude Changes of Hepatitis B Prevention in Pre- Conception Women}

\begin{abstract}
Indonesia is the country with the third most hepatitis $B$ sufferers in the world, with 28 million sufferers. Hepatitis $B$ disease can attack all age level, including pregnant women. If the fetus is infected with the hepatitis $B$ virus, it can cause premature babies, low birth weight babies, anatomical and baby body functions abnormalities. One of the factors causing the high incidence of hepatitis $B$ is the lack of knowledge and public awareness of the disease. Animated video is one of the media that can be used to increase knowledge to the public about hepatitis $B$ and has many advantages compared to other media. The purpose of this study was to analyze the effect of "VISIP - HB" on knowledge and attitudes changes of prevention of Hepatitis $B$ in pre-conception women. This study used a quasi-experimental research design with a sample of 50 preconception women. Bivariate analysis test used independent t-test. The results showed that there was a difference in the knowledge of pre-conception women about preventing hepatitis $B$ in pregnancy in the control group and the treatment group with a $p$ value of 0.000 . There were differences in the attitudes of pre-conception women about preventing hepatitis $B$ during pregnancy in the control group and the treatment group with a $p$ value of 0.000 . There is an effect of "VISIP - HB" on changes in knowledge and attitudes of pre-conception women in preventing hepatitis $B$ during pregnancy.
\end{abstract}

Keywords: knowledge; attitude; videos; pre-conception woman 


\section{LATAR BELAKANG}

Penyakit hepatitis merupakan masalah kesehatan masyarakat di dunia yang dapat meningkatkan mortalitas dan morbiditas. Salah satu jenis hepatitis adalah hepatitis $B$. Menurut WHO virus hepatitis $B$ telah menyebabkan 1,34 juta kematian dan diperkirakan terdapat 257 juta orang hidup dengan infeksi virus Hepatitis B kronik (WHO, 2017). Indonesia merupakan Negara dengan endemis tinggi Hepatitis B terbesar kedua di negara South East Asian Region (SEAR). Menurut Riskesdas (2017) Indonesia menjadi negara dengan penderita Hepatitis B ketiga terbanyak di dunia dengan jumlah penderita 28 juta orang. Penyakit Hepatitis B dapat menyerang semua umur, gender dan ras di seluruh dunia. Hepatitis B dapat menyerang dengan atau tanpa gejala Hepatitis. Ibu hamil termasuk salah satu kelompok yang mudah terinfeksi Hepatitis.

Tahun 2017 terdapat 5,3 juta (2,7\%) ibu hamil dengan Hepatitis B (HBsAg) reaktif dan setiap tahun diperkirakan terdapat 150 ribu bayi yang 95\% berpotensi mengalami hepatitis kronis (sirosis atau kanker hati) pada 30 tahun kedepan. Penyakit Hepatitis B merupakan peradangan atau infeksi pada sel-sel hati yang disebabkan oleh virus Hepatitis B. Peradangan hati dapat menyebabkan kerusakan sel-sel, jaringan, dan bahkan semua bagian organ hati. Wanita hamil yang terinfeksi virus hepatitis $B$ dapat melahirkan bayi prematur, bayi lahir dengan berat rendah (BBLR), atau kelainan anatomi dan fungsi tubuh bayi (terutama pada infeksi hepatitis B kronis). Selain itu, ibu hamil dengan hepatitis $\mathrm{B}$ pada saat melahirkan berpotensi menularkan virus tersebut sekitar 90-95\% pada bayi yang dilahirkan. Hal tersebut ditularkan melalui paparan darah dan cairan vagina ibu saat proses persalinan. Apabila anak terinfeksi virus hepatitis B semenjak lahir, sebagian besar kasusnya akan berlanjut menjadi kronis. Hepatitis kronis inilah yang bisa berakibat buruk pada kesehatan anak di kemudian hari, yaitu berupa kerusakan hati (sirosis) dan kanker hati (terutama jika disertai infeksi virus hepatitis B) (Han, 2012)

Epidemiologi Hepatitis B merupakan sebuah fenomena gunung es, dimana penderita yang tercatat atau yang datang ke layanan kesehatan lebih sedikit dari jumlah penderita yang sesungguhnya. Hepatitis B merupakan penyakit kronis yang menahun, dimana pada saat orang tersebut telah terinfeksi, kondisinya masih sehat dan belum menunjukkan gejala dan tanda yang khas, tetapi penularannya terus berjalan (Kementerian Kesehatan RI, 2014). Salah satu faktor penyebab tingginya kejadian hepatitis $B$ adalah rendahnya pengetahuan dan kesadaran masyarakat terhadap penyakit tersebut. Pada hasil penelitian yang dilakukan oleh Zulfian, dkk (2017) menyatakan bahwa salah satu factor yang menyebabkan kejadian hepatitis B pada ibu hamil adalah pengetahuan. Pada penelitian tersebut menyatakan bahwa 37 dari 52 responden, sekitar $71,2 \%$ responden ibu hamil mempunyai pengetahuan yang kurang tentang hepatitis $\mathrm{B}$.

Tripel eliminasi merupakan salah satu program upaya pemerintah Indonesia untuk menurunkan angka mortalitas dan morbiditas penyakit menular pada ibu hamil. Salah satunya adalah eliminasi pada penyakit hepatitis B. Program tersebut bertujuan untuk memutus penularan Hepatitis $B$ dari ibu ke anak dan menurunkan angka kesakitan, kecacatan, dan kematian akibat Hepatitis B pada ibu dan anak. Target pada program tersebut adalah menurunkan angka kejadian baru akibat penularan pada anak kurang dari atau sama dengan 50/100.000 (lima puluh per seratus ribu) kelahiran hidup pada tahun 2022. Tindakan preventif sedini mungkin untuk meminimalisir ngka kejadian hepatitis $B$ baru merupakan salah satu upaya untuk mencapai target program tripel eliminasi (Permenkes, 2017).

Salah satu tindakan preventif tersebut adalah memberikan pendidikan kesehatan tentang kejadian dan dampak hepatitis B pada masa kehamilan. Tindakan tersebut dapat dilakukan di kalangan wanita usia subur prakonsepsi sebagai upaya persiapan kehamilan yang sehat dan bebas dari infeksi virus hepatitis B. Pemberian pendidikan tersebut juga bertujuan untuk mengubah pengetahuan dan sikap wanita usia subur pra-konsepsi tentang penyakita hepatitis $\mathrm{B}$. Media yang akan digunakan dalam penyuluhan tersebut berupa 
video animasi. Penggunaan media video animasi mempunyai kelebihan, diantaranya adalah memberikan visualisasi yang baik sehingga memudahkan proses penyerapan pengetahuan. Video termasuk dalam media audio visual karena melibatkan indera pendengaran sekaligus indera penglihatan. Media audio visual ini mampu membuahkan hasil belajar yang lebih baik untuk tugas-tugas seperti mengingat, mengenali, mengingat kembali dan menghubungkan fakta dan konsep. Media audio visual mempunyai banyak

\section{METODE}

Jenis penelitian ini adalah penelitian kuantitatif dengan metode quasi experimental reaseach yaitu memberikan suatu perlakuan dengan menggunakan rancangan randomised perspective study. Desain penelitian yang digunakan adalah pre test-post test countrol group design. Populasi dalam penelitian adalah seluruh wanita pra konsepsi di wilayah UPT Puskesmas Blora.

Jumlah sampel pada penelitian ini adalah 50 WUS. Instrumen pengumpulan data yang digunakan pada penelitian ini adalah kuesioner. Pada pengambilan data penelitian ini membagi subyek menjadi 2 kelompok, yaitu kelompok perlakuan dan kelompok kontrol. kelebihan dibandingkan dengan media lainnya (Kustandi, 2011). Penyuluhan menggunakan media video animasi ini dapat diakses oleh semua masyarakat, tampilannya menarik dan tidak monoton, simple dapat di bawa kemana mana, karena dapat dilihat dengan media HP serta dapat dilihat berulang ulang. Berdasarkan permasalahan tersebut, penelitian dilakukan untuk menganalisa pengaruh "VISIP - HB" (Video Animasi Pencegahan Hepatitis B) terhadap perubahan pengetahuan dan sikap pencegahan Hepatitis B wanita pra konsepsi.

Kelompok perlakuan mendapatkan penyuluhan kesehatan menggunakan VISIP-HB (video animasi pencegahan hepatitis $\mathrm{B}$ ). Kelompok kontrol mendapatkan penyuluhan secara langsung tentang pencegahan hepatitis B pada kehamilan. Kedua kelompok mendapatkan pre test sebelum diberikan intervensi dan post test setelah dilakukan intervensi. Pada penelitian ini menggunakan Analisis bivariate menggunakan uji independent $t$ test pada variable yang datanya berdistribusi normal, sedangkan menggunakan uji Mann Whitney pada variable yang datanya berdistribusi tidak normal. Nomor Etichal clearence pada penelitian ini: No.189/EA/KEPK/2020.

\section{HASIL}

Karakteristik responden

Sampel penelitian ini adalah wanita pra konsepsi sebanyak 50 responden yang memenuhi kriteria inklusi dan eksklusi. Karakteristik responden dapat dilihat pada tabel berikut

Tabel 1. Karakteristik responden

\begin{tabular}{|c|c|c|c|c|c|}
\hline \multicolumn{2}{|c|}{ Karakteristik } & \multicolumn{2}{|c|}{ Kelompok Perlakuan } & \multicolumn{2}{|c|}{ Kelompok Kontrol } \\
\hline & & $\mathrm{n}$ & $\%$ & $\mathrm{~N}$ & $\%$ \\
\hline \multirow[t]{3}{*}{ Umur } & $<20$ tahun & 3 & 12 & 2 & 8 \\
\hline & 20-35 tahun & 20 & 80 & 21 & 84 \\
\hline & $>35$ tahun & 2 & 8 & 2 & 8 \\
\hline \multirow{4}{*}{ Pendidikan } & SD & 4 & 16 & 5 & 20 \\
\hline & SMP & 6 & 24 & 8 & 32 \\
\hline & SMA & 13 & 52 & 10 & 40 \\
\hline & D3/S1 & 2 & 8 & 2 & 8 \\
\hline
\end{tabular}


Tabel 1 menunjukkan karakteristik responden, dapat diketahui bahwa sebagian responden dalam penelitian ini berusia reproduktif (20-35 tahun), pada kelompok kontrol sebanyak 25 responden (92.6\%) dari 27 responden $(100 \%)$ dan kelompok perlakuan sebanyak 24 responden (88.8\%) dari 27 responden (100\%). Pada karakteristik pendidikan responden paling banyak dengan pendidikan SMA, pada kelompok kontrol sebanyak 20 responden (74\%) dari 27 responden (100\%) dan kelompok perlakuan sebanyak 21 responden (77.7\%) dari 27 responden (100\%).

Umur adalah usia individu yang terhitung mulai saat dilahirkan sampai saat beberapa tahun. Pada penelitian ini sebagian besar responden kelompok control. maupun perlakuan adalah berusia 20-35 tahun, yaitu sebanyak 41 responden (82\%). Wanita usia 20-35 tahun adalah usia reproduktif.

Dimana pada usia tersebut seorang wanita cenderung mempersiapkan masa kehamilan dan sudah siap baik dari segi organ reproduksi, keterampilan dalam merawat diri dan bayi serta psikologis yang stabil. Pada usia tersebut juga menunjukan sifat berfikir yang sudah matang dan memiliki mental yang diperlukan untuk mempelajari dan menyesuaikan diri pada situasi baru, misalnya mengingat hal hal yang pernah dipelajari, penalaran analogy dan berfikir kreatif. Sehingga responden pada penelitian ini akan lebih mudah meningkatkan pengetahuan dan sikap tentang pencegahan hepatitis B pada masa kehamilan. Selain itu menurut peneliti dengan usia responden tersebut mencerminkan kematangan seseorang dalam mengambil keputusan dalam hal ini adalah keputusan untuk melakukan upaya pencegahan hepatitis $B$ pada masa kehamilan (Notoatmojo, 2007). Menurut Hurlock (2000) bahwa usia dewasa muda dapat mengembangkan keinginannya dalam mencari tahu peran-peran baru. Hal tersebut berasumsi bahwa pada tahapan usia ini seseorang semakin bertambah dalam memainkan peran baru sehingga dalam keterlibatan pembelajaran yang berorientasi kognitif seperti yang dilakukan dalam intervensi penelitian adalah memberikan pendidikan kesehatan menggunakan media video, sehingga responden merasa lebih tertarik untuk mempelajari tentang pencegahan hepatitis $B$ pada masa kehamilan.

Pada penelitian ini sebagian besar responden pada kedua kelompok mempunyai tingkat pendidikan SMA, yaitu sebanyak 33 responden (66\%). Tingkat pendidikan merupakan sarana untuk merespon informasi yang diterima dengan baik. Semakin tinggi pendidikan seseorang maka akan semakin mudah seseorang untuk menerima informasi dan semakin banyak pula pengalaman yang dimilikinya. Pendidikan yang kurang akan menghambat pengetahuan perkembangan sikap seseorang terhadap nilai nilai yang baru diperkenalkan. Loundon dan brita (2009) menjelaskan bahwa semakin tinggi tingkat pendidikan seseorang maka semakin tinggi keinginan dan harapan. Dalam penelitian ini keinginan dan harapan wanita dalam memperoleh dan mengubah pengetahuan dan sikap menjadi lebih baik terhadap pencegahan hepatitis B pada masa kehamilan. Pada jenjang pendidikan SMA maka pemikiran responden dalam mencerna suatu pengalaman baru untuk 27 menambah pengetahuan akan lebih mudah untuk diterima. Selain itu tingkat pendidikan juga sebagai sarana untuk pemberdayaan individu sehingga dapat meningkatkan pengetahuan dan mengubah sikap menjadi lebih positif dalam pengembangan diri. Oleh karena itu wanita pra konsepsi yang memiliki pendidikan relative tinggi akan selalu mengembangkan wawasan dan mengikuti perkembangan baru terutama informasi tentang gizi dan upaya pencegahan hepatitis B pada masa kehamilan (Notoatmojo, 2007). 
Pengetahuan WUS

Pada tabel 2 menggambarkan pengetahuan WUS tentang pencegahan Hepatitis B pada kehamilan sebelum dan setelah diberikan penyuluhan menggunakan VISIP - HB" (Video Animasi Hepatitis B).

Tabel 2. Pengetahuan

\begin{tabular}{|c|c|c|c|c|c|c|c|}
\hline \multirow[t]{2}{*}{ Karakteristik } & & \multicolumn{2}{|c|}{$\begin{array}{l}\text { Kelompok } \\
\text { Perlakuan }\end{array}$} & \multicolumn{2}{|c|}{$\begin{array}{l}\text { Kelompok } \\
\text { Kontrol }\end{array}$} & \multicolumn{2}{|c|}{ Total } \\
\hline & & $n$ & $\%$ & $n$ & $\%$ & $\mathrm{n}$ & $\%$ \\
\hline \multirow{2}{*}{ Pengetahuan Pre test } & Baik & 10 & 18.5 & 11 & 20.4 & 21 & 40 \\
\hline & Kurang & 17 & 31.5 & 16 & 29.6 & 33 & 60 \\
\hline \multirow{2}{*}{ Pengetahuan Post test } & Baik & 18 & 33.3 & 15 & 27.7 & 33 & 61 \\
\hline & Kurang & 9 & 16.7 & 12 & 22.3 & 21 & 39 \\
\hline
\end{tabular}

Sumber: Data Primer, 2019

Pada tabel diatas pengetahuan WUS pada pre test kedua kelompok paling banyak adalah kurang, yaitu pada kelompok control dengan prosentase $29.6 \%$ dan kelompok pelakuan dengan prosentase $31.5 \%$.
Pengetahuan WUS pada post test ke dua kelompok paling banyak adalah responden dengan pengetahuan baik (kelompok kontrol $33.3 \%$ dan pelakuan $27.7 \%$ ).

Sikap WUS

Gambaran Sikap WUS tentang pencegahan Hepatitis B pada kehamilan sebelum dan setelah diberikan penyuluhan menggunakan VISIP - HB" (Video Animasi Hepatitis B).

Tabel 3. sikap WUS

\begin{tabular}{llcccccc}
\hline \multirow{2}{*}{ Sikap } & & \multicolumn{2}{c}{ Kelompok } & \multicolumn{2}{c}{ Kelompok } & \multicolumn{2}{c}{ Total } \\
& & \multicolumn{2}{c}{ Perlakuan } & \multicolumn{2}{c}{ Kontrol } & & \\
\hline Pre Test & Positif & 15 & 27.7 & 15 & 27.7 & 30 & 52 \\
& Negatif & 12 & 22.3 & 12 & 22.3 & 24 & 48 \\
Post Test & Positif & 17 & 31.5 & 14 & 26 & 31 & 57.4 \\
& Negatif & 10 & 18.5 & 13 & 24 & 23 & 42.6 \\
\hline
\end{tabular}

Sumber: Data Primer, 2019

Pada tabel diatas sikap wanita pra konsepsi pada pre test kedua kelompok adalah postitif (kelompok kontrol 27.7\% dan pelakuan
27.7\%). Sikap wanita pra konsepsi pada post test ke dua kelompok adalah positif (kelompok kontrol $26 \%$ dan pelakuan 31.5\%).

\section{Perbedaan pemberian VISIP - HB" (Video Animasi Hepatitis B) terhadap pengetahuan wanita pra konsepsi}

Tabel 4. Uji Beda pre post pengetahuan pada masing-masing kelompok

\begin{tabular}{cccccc}
\hline Pengetahuan & \multicolumn{2}{c}{ Pre } & \multicolumn{2}{c}{ Post } & \multirow{2}{*}{ P value } \\
\cline { 2 - 5 } & Mean & SD & Mean & SD & \\
\hline Kontrol & 30.52 & 3.380 & 32.96 & 3.846 & 0.042 \\
Perlakuan & 31.08 & 3.662 & 33.08 & 3.616 & 0.04 \\
\hline
\end{tabular}

Sumber: Data Primer, 2020 
Tabel 4 menjelaskan tingkat pengetahuan wanita pra konsepsi tentang pencegahan Hepatitis B pada masa kehamilan sebelum dan sesudah diberikan intervensi pada kelompok kontrol dan perlakuan. Hasil dari uji normalitas pada kelompok kontrol dan kelompok perlakuan adalah data berdistribusi normal (p>0.05). Hasil dari uji paired $t$ test menunjukkan pada kelompok kontrol ada perbedaan antara pre test dan post test $p=0.042(p<0.05)$ dan kelompok perlakuan ada perbedaan antara pre test dan post test $p=0.04$ $(P<0.05)$.

Tabel 5. Uji Beda pengetahuan antar kelompok

\begin{tabular}{llllc}
\hline & Pengetahuan & $\mathrm{n}$ & Mean & p value \\
\hline \multirow{2}{*}{ Pre test } & Kontrol & 27 & 24.24 & 0.538 \\
\multirow{3}{*}{ Post test } & Perlakuan & 27 & 26.76 & \\
& Kontrol & 27 & 32.96 & 0.91 \\
& Perlakuan & 27 & 33.08 & \\
\hline
\end{tabular}

Sumber: Data Primer, 2019

Tabel 5 menunjukkan perbedaan antara 2 kelompok kontrol dan perlakuan. Pada pre test pengetahuan antara kedua kelompok menghasilkan distribusi data tidak normal ( $p<0.05$ ). Uji yang digunakan adalah uji mann withney dengan hasil $p=0.538$ ( $p>0.05)$ artinya tidak ada perbedaan pre pengetahuan antara kelompok perlakuan dan kontrol. Pada post test sikap uji normalitas menunjukkan dat normal $(p>0.05)$. Uji yang digunakan uji independent $t$ test dengan hasil $p=0.91$ artinya tidak ada perbedaan antara kedua kelompok. Jika dilihat dari nilai mean terdapat perbedaan, kelompok yang mendapatkan pendidikan kesehatan menggunakan VISIP - HB" (Video Animasi Hepatitis B) mempunyai rata-rata skor pengetahuan lebih besar 33.08 dibandingkan dengan kelompok kelompok control yaitu 32.96 .

Perbedaan pemberian VISIP - HB" (Video Animasi Hepatitis B) terhadap sikap wanita pra konsepsi

Tabel 6. Uji Beda pre post sikap pada masing-masing kelompok

\begin{tabular}{lccccc}
\hline & \multicolumn{2}{c}{ Pre } & \multicolumn{2}{c}{ Post } & \multirow{2}{*}{ P value } \\
\cline { 2 - 5 } & Mean & SD & Mean & SD & \\
\hline Kontrol & 39.28 & 4.088 & 42.96 & 3.116 & 0.001 \\
Perlakuan & 38.92 & 2.957 & 43.24 & 3.257 & 0.000 \\
\hline
\end{tabular}

Sumber: Data Primer, 2019

Pada tabel diatas menjelaskan sikap sebelum dan sesudah pada kelompok kontrol dan perlakuan. Uji normalitas dilakukan dengan hasil pada kelompok kontrol dan kelompok perlakuan yaitu distribusi data normal ( $p>0.05)$.
Hasil dari uji paired t test menunjukkan pada kelompok kontrol ada perbedaan antara sebelum dan sesudah $p=0.001(p<0.05)$ dan kelompok perlakuan ada perbedaan antara sebelum dan sesudah $p=0.000 \quad(P<0.05)$.

Tabel 7. Uji Beda sikap antar kelompok

\begin{tabular}{llllc}
\hline & Sikap & $\mathrm{n}$ & Mean & p value \\
\hline \multirow{3}{*}{ Pre test } & Kontrol & 27 & 39.28 & 0.723 \\
& Perlakuan & 27 & 38.92 & \\
Post test & Kontrol & 27 & 24.84 & 0.746 \\
& Perlakuan & 27 & 26.16 & \\
& &
\end{tabular}

Sumber: Data Primer, 2019 
Tabel diatas menunjukkan perbedaan antara 2 kelompok kontrol dan perlakuan. Pada pre test sikap antara kedua kelompok menghasilkan distribusi data normal ( $p>0.05)$. Uji yang digunakan adalah uji independent $t$ test dengan hasil $p=0.723 \quad(p>0.05)$ artinya tidak ada perbedaan pre sikap antara kelompok perlakuan dan kontrol. Pada post test kinerja uji normalitas menunjukkan data tidak normal $(p<0.05)$. Uji yang digunakan uji mann withney dengan hasil $p=0.746$ artinya tidak ada perbedaan antara kedua kelompok. Namun jika dilihat dari nilai mean ada perbedaan antara kelompok kontrol dan perlakuan dimana kelompok yang diberikan pendidikan kesehatan menggunakan pemberian VISIP - HB" (Video Animasi Hepatitis B) mempunyai rata-rata skor sikap lebih besar 26.16 dibandingkan kelompok kontrol 24.84 .

\section{PEMBAHASAN}

Pada hasil penelitian diketahui bahwa terdapat perbedaan sik ap antara kelompok perlakuan (pemberian video animasi/audiovisual) dan kelompok kontrol dengan nilai beda mean paling besar pada kelompok perlakuan (pemberian video animasi/audiovisual). Pada penelitian ini terdapat pengaruh yang signifikan penggunaan media audio visual terhadap sikap wanita pra konsepsi dalam melakukan upaya pencegahan hepatitis B pada masa kehamilan. Sikap adalah perasaan positif atau negatif sebagai respon seseorang terhadap suatu objek, orang dan lingkungan sebagai hasil dari pengetahuan dan pengalaman yang telah didapatkan. Sikap sendiri memiliki 4 tingkatan yaitu menerima, merespon, menghargai dan bertanggung jawab.

Peningkatan sikap wanita pra konsepsi terhadap pencegahan hepatitis B pada masa kehamilan disebabkan karena pemberian edukasi menggunakan media VISIP-HB (Video Animasi Pencegahan Hepatitis B). Seperti yang dikemukakan oleh Wawan dan Dewi bahwa sikap dipengaruhi oleh beberapa faktor, diantaranya pengalaman pribadi, pengaruh orang lain, pengaruh budaya setempat, media massa, lembaga pendidikan atau lembaga agama, dan factor emosional. Hal ini sejalan dengan penelitian Zakaria (2017) yang menjelaskan bahwa ada pengaruh signifikan penggunaan media audiovisual terhadap sikap ibu hamil tentang inisiasi menyusui dini. Ibu hamil yang mendapatkan pendidikan menggunakan audiovisual memiliki peningkatan sikap yang lebih signifikan dibandingkan dengan yang hanya menggunakan media visual saja. Hal ini karena pada media audiovisual juga lebih menarik perhatian, menghemat waktu dan dapat diputar berulang-ulang. Banyak media yang dapat digunakan untuk memberikan pendidikan kesehatan salah satunya adalah dengan menggunakan media video.

Hasil penelitian ini juga sama dengan hasil penelitian yang dilakukan oleh oleh Jafar, RS (2020) bahwa pemberian media video dapat mempengaruhi sikap responden sebelum dan sesudah diberikan pendidikan kesehatan tentang hepatitis B. Sikap seseorang dapat berubah melihat video. Sama halnya dengan pengetahuan, sikap adalah bentuk perilalu tertutup, sehingga orang lain tidak dapat melihat atau mengamati adanya peruibahan perilaku dari individu. Sikap merupakan respon atau keinginan untuk melakukan tindakan, dalam hal ini tindakan remaja dalam mencegah factor risiko terjadinya hepatitis B. Media animasi mempunyai kemampuan besar untuk menarik perhatian, memengaruhi sikap dan tingkah laku (Sadiman AS, 2014). Penggunaan media animasi juga memengaruhi perubahan sikap subjek menjadi semakin baik setelah melihat tayangan animasi. Azwar (2010) menyatakan bahwa faktor-faktor yang mempengaruhi sikap ialah media penyampaian informasi yang biasanya berisi sugesti untuk mengarahkan opini seseorang. Bila sugesti cukup kuat maka akan memberikan dasar afektif dalam menilai sesuatu hal sehingga terbentuk arah sikap yang diwujudkan melalui tindakan. Sebelum diberikan pendidikan kesehatan dengan media audio visual mayoritas subjek memiliki sikap negatif. Setelah diberikan pendidikan kesehatan dengan media animasi, terjadi perubahan sehingga mayoritas subjek memiliki sikap positif. Sikap merupakan reaksi yang 
masih tertutup dari seseorang terhadap stimulus atau objek yang disertai dengan kecenderungan untuk bertindak (Notoatmodjo, 2003).

\section{KESIMPULAN DAN SARAN}

Pada penelitian ini ada perbedaan pre dan post test sikap wanita pra konsepsi tentang pencegahan hepatitis $B$ pada kehamilan pada kelompok kontrol dan kelompok perlakuan. Ada

\section{REFERENSI}

Azwar S. (2013). Sikap Manusia: Teori dan Pengukurannya. Yogyakarta: Pustaka Pelajar.

Dunkelberg, JC., EMF Berkley, KW Thiel, KK Leslie. (2014). Hepatitis B and C in Pregnancy: a Review and Recommendations for Care. Journal

Godbole G, Irish D, Basarab M, Mahungu T, Lewis AF, Thorne C, et al. (2013). Management of hepatitis

from four London hospitals. BMC Pregnancy and Childbirth.

Han, Guo-Rong. Chuan-Lu Xu, Wei Zhao, Yong-Feng Yang. (2012). Management of Chronic Hepatitis B in Pregnancy. World J Gastroenterol, 18(33): 4517-4521.

Hurlock, BE. (2000). Psikologi Perkembangan: Suatu Pengantar Sepanjang Rentang Kehidupan. Jakarta: Erlangga.

Jafar RS. (2020). Pendidikan Kesehatan Pada Remaja Tentang Faktor Risiko Berhubungan Penyakit Hepatitis B Dengan Media Video. Poltekkes Kemenkes Mataram. Media Bina IImiah: Vol.14 No.7. ISSN 2615-3505

Kustandi, C, Sujipto, B. (2011). Media Pembelajaran Manual dan Digital. Bogor: Penerbit Ghalia Indonesia.

Kemenkes RI. (2014). Hepatitis B pada Masa Kehamilan. Jakarta: Depkes RI.

Lao TT, Sahota DS, Law LW, Cheng YKY, and Leung TY. (2014). Age-Specific Prevalence of Hepatitis $B$ Virus Infectionin Young Pregnant Women, Hong Kong Special Administrative Region of China. Bulletin of the World Health Organization. 92(11): 782-789. pengaruh media VISIP-HB (Video animasi pencegahan Hepatitis B) terhadap pengetahuan dan sikap wanita pra konsepsi dalam melakukan pencegahan hepatitis B pada kehamilan. Media video animasi pada penelitian dapat digunakan sebagai media untuk mempromosikan kepada masyarakat sebagai upaya mencegah terjadinya hepatitis $B$ pada masa kehamilan.

PerdysomK, Waller J, Turley A, et al. Hepatitis B in Pregnancy.Frontline Gastroenterology. 5(2):111117

Dyson JK, Waller J, Turley A, et al. (2014). Hepatitis B in Pregnancy. Frontline Gastroenterology.; 5(2): 111-117.

$B$ in pregnant women and infants: a multicenter audit

Notoatmodjo, S. (2007). Pendidikan Dan Perilaku Kesehatan. Jakarta: PT. Rineka Cipta.

Permenkes. (2017). Eliminasi Penularan Human Immunodeficiency Virus, Sifilis, Dan Hepatitis B Dari Ibu Ke Anak. Jakarta: Menkes RI.

Riskesdas. (2017). Riset Kesehatan Dasar. Jakarta: Kementerian Kesehatan Republik Indonesia.

Sadiman, AS. (2014). Media Pendidikan, Pengertian, Pengembangan, dan. Pemanfaatannya. Jakarta: Rineka Cipta.

Sugiyono. (2013). Metode Penelitian kuantitatif, Kualitatif dan R \& D. Bandung: Alfabeta.

World Health Organization. (2017). Guidelines for the Prevention Care and Treatment of Persons with Chronic Hepatitis B Infection. Geneva: World Health Organization.

Zakaria F, Rono H, Farida K. (2017) Pengaruh Pendidikan Kesehatan dengan media audiovisual terhadap sikap ibu hamil tentang inisiasi menyusui dini. Jurnal Kebidanan dan Keperawatan, Vol.13, No. 2, 128-14.

Zulfian, Setiawati OR, Sapitia A. (2018). Hubungan Tingkat Pengetahuan Ibu Hamil Dengan Kejadian Hepatitis B Di Puskesmas Beringin Kecamatan Lubai Kota Palembang. Jurnal IImu Kedokteran Dan Kesehatan, Volume 5, Nomor 3 